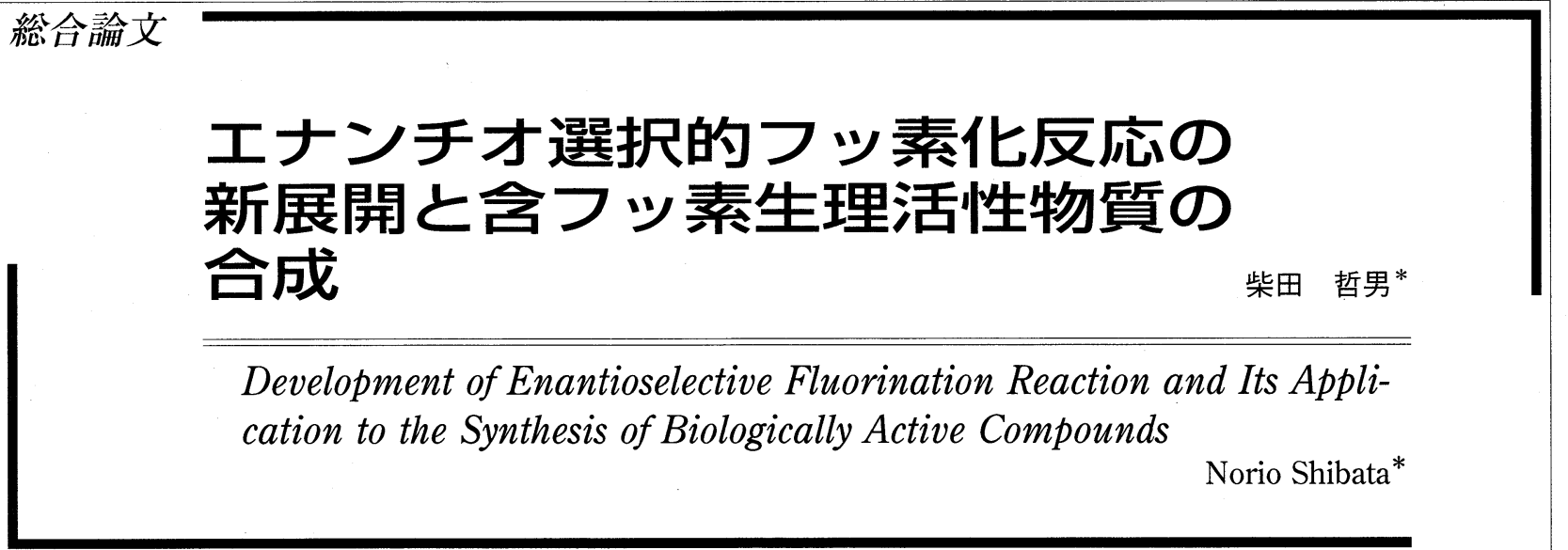

\begin{abstract}
The selective construction of carbon-fluorine bonds is of great interest to medicinal chemists because the replacement of hydrogen and oxygen atoms with fluorine atom in biologically active molecules can confer molecules with improved physicochemical properties and biological activities. Since the first discovery of enantioselective fluorination using $N$-fluorocamphorsultam, our synthetic interests have been focused on the development of chiral $N$-fluorosulfonamide derivatives capable of enantioselective fluorination. However, these initial efforts revealed several limitations in both chemical yields and enantioselectivities of the fluorinated products. We present here the background of our recent development of the enantioselective fluorination reaction and some successful applications of the methods to the design and synthesis of fluoroisosteres of biologically active natural products. Two novel approaches using the cinchona alkaloids/Selectfluor ${ }^{\circledR}$ combi- $^{-}$ nation and bis (oxazoline)-metal complex have been pursued, respectively. Cinchona alkaloid/ Selectfluor ${ }^{\circledR}$ combination, i.e., $N$-fluoroammonium salts of cinchona alkaloids, was found to be an effective enantioselective fluorinating reagent for a wide range of substrates such as silyl enol ethers, $\beta$-keto esters, arylcyano esters, and oxindoles without any additives. The bis(oxazoline)s were found to be efficient and unique catalysts for enantioselective fluorination in the presence of a catalytic amount of metal salts. An interesting phenomenon, "elective" enantioselectivity, has been observed in the fluorination of $\beta$-keto esters. Switching the metal center from copper to nickel in the presence of the same bis(oxazoline) ligands gave a complete reversal of enantioselectivity.

Key words: enantioselective fluorination, cinchona alkaloids, bis(oxazoline)s, natural products, medicinal chemistry
\end{abstract}

はじめに

有機合成化学の医療領域への展開は, 創薬化学という 形で着実な進歩を遂げている。とりわけ，等価性の概念 に基ついて，生理活性物質上の原子の一部を，電子的あ るいは立体的見地の上で等価な他の元素に置き換える方 略は，新しい生理活性物質を設計する上で，重要かつ信 頼性の高い方法である。等価性の考え方には物理化学的 なものと生物学的なものとがあるが，よく行われる例と して， 2 価の酸素原子 $(\mathrm{O})$ を硫黄原子 $(\mathrm{S})$ やアミノ基 $(\mathrm{NH})$ ，あるいはメチレン基 $\left(\mathrm{CH}_{2}\right)$ に元素交換する方法 が知られている。1価の元素の場合には，交換候補元素 としてフッ素が注目されている1)。そもそもフッ素原子

\section{4 年度有機合成化学奖励賞受賞}

* 名古屋工業大学大学院工学研究科ながれ領域

* Department of Applied Chemistry, Graduate School of Engineering, Nagoya Institute of Technology
を有する有機化合物は，天然からはあまり見つかってい ない。それにもかかわらず医薬品を例にとってみると, ニューキノロン系を代表に含フッ素医薬品の成功例は多 い。例えば, 2003 年度における医薬品売上高べスト 20 をみると含フッ素医薬品が 6 品目エントリーしてい る2)。医薬品における成功例は，以下にあげるような フッ素の性質によるところが大きい。まず，フッ素は水 素についで小さい原子であり, 生理活性化合物中の水素 原子をフッ素に置換しても立体的には大きな变化がない ために，生体はその微妙な差異を識別できず，元の生理 活性化合物と同じように取り込んでしまう。これはフッ 素の擬似効果 (mimic 効果) と呼ばれるものである。擬 似効果により生体に取り达まれたフッ素置換体は, C-F 結合の結合エネルギーが $\mathrm{C}-\mathrm{H}$ 結合のエネルギーに比ベ てはるかに大きいことなど，水素置換体と全く異なる化 学的性質を持っているため, 通常の代謝経路による生体 反応を受けなくなり (block 効果), その生理活性に様々 な影響を及ぼすと考えられる。また，電気陰性度が 4.0 であることを考慮すると, 水素原子よりもむしろ酸素原 
子に近いと解釈することもでき, 水酸基 $(\mathrm{OH})$ のミミッ クともいわれている。いずれにしても脂溶性の点などに 関しては，水素および酸素のどちらとも大きく異なるこ とから (脂溶性を変化させる効果), その生理活性に興味 深い影響を及ぼす確率が高くなるといえよう。

さて, このような観点から, 有機化合物へフッ素原子 を導入するための試薬や方法論が多数開発されてきた。 しかしながら, 現在知られている含フッ素医薬品は, ベ ンゼン環や複素環などの芳香族上の水素原子をフッ素や トリフルオロメチルに置換した例ばかりが目立ち, 含 フッ素ステロイド医薬品に代表されるような不斉中心に フッ素原子を有する医薬品や農薬品は少ない。これは, 不斉中心にフッ素原子を選択的に導入する実用的な不斉 フッ素化試薬やフッ素化反応がないことにも起因する。

不斉フッ素化試薬の研究は, 1989 年, スイスのチバ 社での Diffferding, Lang によるカンファーフルオロス ルタムの研究3)から始まった。当時, フルオロスルホン アミド系フッ素化試薬を精力的に研究していた彼らは, 天然物のカンファーから容易に誘導される光学活性な環 状スルホンアミド化合物に着目した。光学活性体, スル ホンアミド, 環状構造といった不斉フッ素化試薬として の目的にかなう構造をすべて備えたこの化合物は，フッ 素ガスにて容易にフッ素化され, 安定な結晶性のカン ファーフルオロスルタム(図 1)を与えた。残念ながらこ の試薬は, 目的物を得るには, 化学収率および不斉収率 ともに不十分なものであったが, 光学活性なフルオロス ルタム化合物が不斉フッ素化試薬として有効である可能 性を示した最初の例として重要である。この報告に触発 され, 光学活性フルオロスルタム型不斉フッ素化試薬の 探索研究 ${ }^{4)}$ が各地で開始された。発表されたフルオロス ルタム型試薬は, ある程度の不斉収率で対応するフルオ 口体を与えたが，いずれの試薬も開発した研究者以外に 使用された形跡がないなど，高い評価を得るには至らな かった。

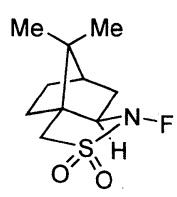

Fig. 1

暗礁に乗り上げていたこの研究領域は，21 世紀の到 来に呼応して大きく動き出した。我々は, 実用的な不斉 フッ素化試薬の開発研究に取り組んだ結果, フルオロス ルホンアミド型不斉フッ素化試薬から脱却したキナアル カロイド/Selectfluor ${ }^{\circledR}$ 試薬を開発することに成功した。 この試薬は，2 種の市販試薬を有機溶媒中で混合するだ けで簡単に調製できるキラルフルオロアンモニウム塩で
ある。簡便に反応を実施でき，適応範囲が広く，しかも 不斉収率は従来法に比べ格段に高いなど，これまでには ない優れた性能を備えていた。驚いたことに，同じ考え 方での不斉フッ素化試薬がほぼ同時期にフランスからも 報告された5)。またスイスからは，今後の主流となる二 点配位を利用するチタン/酒石酸触媒を用いる触媒的不 斉フッ素化法 ${ }^{6}$ が発表されるなど, この年は不斉フッ素 化反応の開発研究にとって転換期となった。本稿では, 筆者らの開発したキナアルカロイド/Selectfluor ${ }^{\circledR}$ 試薬 から，ビスオキサゾリジン型化合物を用いる触媒的不斉 フッ素化法の開発, またそれらを用いる含フッ素生理活 性物質の合成など, 我々の研究を中心に紹介する。な お, 他グループによる研究成果については, 引用した総 説中に記載されているそれぞれの原報を参照されたい。

\section{1. キナアルカロイド/Selectfluor ${ }^{\circledR}$ 試薬を用いる新 しい不斉フッ素化反応の開発}

\section{1 キナアルカロイドN-フルオロアンモニウム塩 の構造}

筆者らは, 高選択性かつ実用的という社会的要求に応 えるべく, 反応剤の構造に大胆にメスを入れ，これまで のどの範ちゅうにも属さない新試薬の開発に取り組ん だ。第一の課題は, 市販試薬だけで実施可能な新反応系 を見つけ出すことであった。鋭意検討した結果，市販の フッ素化試薬とキナアルカロイド誘導体を混ぜるだけで 簡単に調製できる, 高い不斉フッ素化能力を持つ新試薬 を創出することに成功した7)。キナアルカロイドのフル オロアンモニウム塩である。この試薬は, ジカチオン型 フッ素化試薬 Selectfluor ${ }^{\circledR}$ をナアルカロイドと溶媒中 で混合すると, Selectfluor ${ }^{\circledR}$ のフッ素原子がキナアルカ ロイドのキヌクリジンの三級窒素上に転位することによ り生成する。反応は不安定なジカチオンが安定なモノカ チオンに変換されることが引き金となっている。

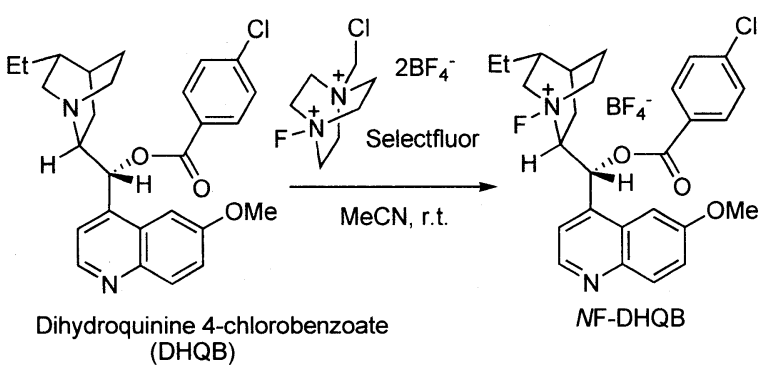

Scheme 1

キナアルカロイドの $N-$ フルオロアンモニウム塩の生 成は ${ }^{19}$ F NMRを用いて確認できる(図 2)。まず, Selectfluor ${ }^{\circledR}$ の ${ }^{19} \mathrm{~F}-\mathrm{NMR}$ を重アセトニトリル中で測定 すると, $N$-フルオロアンモニウム塩のフッ素のシグナ ルが 49 ppm にシングレットとして現れる。ここにキナ 
アルカロイド誘導体, ジヒドロキニン-4-クロロベンゾ エート $(\mathrm{DHQB})$ を 0.5 等量加えると，44 ppm にフルオ ロアンモニウム塩の新しいピークが表れる。さらに DHQB を加えていくと, 49 ppm のピークが徐々に消滅 し，最終的に 1 等量の DHQB を加えた場合には $44 \mathrm{ppm}$ のピークだけになる。これは，キナアルカロイドの $N-$ フルオロアンモニウム塩の存在を強く支持するものであ る。最終的には, 反応溶液から $N-$ フルオロアンモニウ
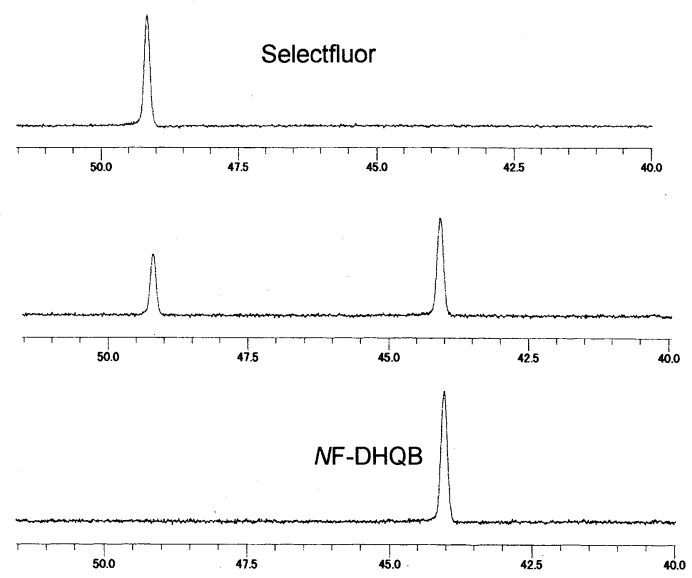

Fig. 2 The $254 \mathrm{MHz}{ }^{19} \mathrm{~F}$ NMR spectrum of Selectfluor and the combination in $\mathrm{CD}_{3} \mathrm{CN}$. Top: Downfield region of the ${ }^{19} \mathrm{~F}$ NMR spectrum of Selectfluor in $\mathrm{CD}_{3} \mathrm{CN}$. Middle: The same region after the addition 0.5 equiv. of DHQB. Bottom: The same region after the addition 1.0 equiv. of $\mathrm{DHQB}$, leading to the quantitative formation of $N F-D H Q B$.
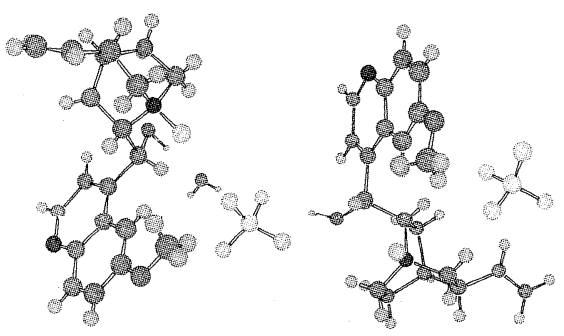

ム塩を取り出し，X線結晶構造解析を行って構造を確認 した。図 3 にキニン $(\mathrm{QN})$ のフルオロアンモニウム塩 $(N F-Q N)$ の構造を示す。キナアルカロイド類は，開い た構造 (Open 型) と閉じた構造 (Closed 型)が存在するこ とが知られている。X 線の結果から，この化合物は開い た構造であることがわかった。また，NF-QN 2 分子に 対し 1 分子の水が含まれていた。それぞれの $N F-Q N$ は C 1-C 2-C 9-C 10 と C 21-C 22-C 29-C 30 の間で若干の コンフォメーションの違いが見られる。フッ素原子はキ ヌクリジン骨格の窒素原子に結合しており, $\mathrm{BF}_{4}{ }^{-}$が対 アニオンとして存在していることがわかる。 N-F 間の

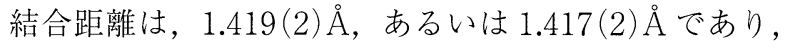
Selectfluor ${ }^{\circledR}$ の N-F 間の結合距離 $1.37(2) \AA よ$ より少し 長いことがわかった。その他の $N$-フルオロアンモニウ ム塩も同様に調製することができる(図 4)。

\section{2 シリルエノールエーテルの不斉フッ素化反応}

キナアルカロイド/Selectfluor ${ }^{\circledR}$ 溶液から得られる NF-DHQB は，シリルエノールエーテルに対する不斉 フッ素化反応において良好な結果を与える。すなわち， DHQB と Selectfluor ${ }^{\circledR}$ を混合して調製したNF-DHQB をー $20{ }^{\circ} \mathrm{C}$ で, インダノンもしくはテトラロンのシリル エノールエーテル 1 と反応させた。その結果，置換基の 種類に大きく影響を受けることなく，高収率で対応する フルオロ体 2 を高いエナンチオ選択性で与えた(表 1)。 なお，キナアルカロイド誘導体 DHQB は Sharpless 不 斉ジヒドロキシル化反応の触媒として開発された化合物 である。

$\mathrm{X}$ 線結晶構造解析の結果をもとに, 1aに対する不斉 フッ素化反応の反応機構を考察した。トリメチルシリル 基招よびベンジル基の立休障害を考えると，図 5 に示し たような反応経路でシリル体が接近することにより $R$ 配置の 2aが得られたと考えている。

Fig. $3 \mathrm{X}$-ray crystallographic structure of $N \mathrm{~F}-\mathrm{QN}$.
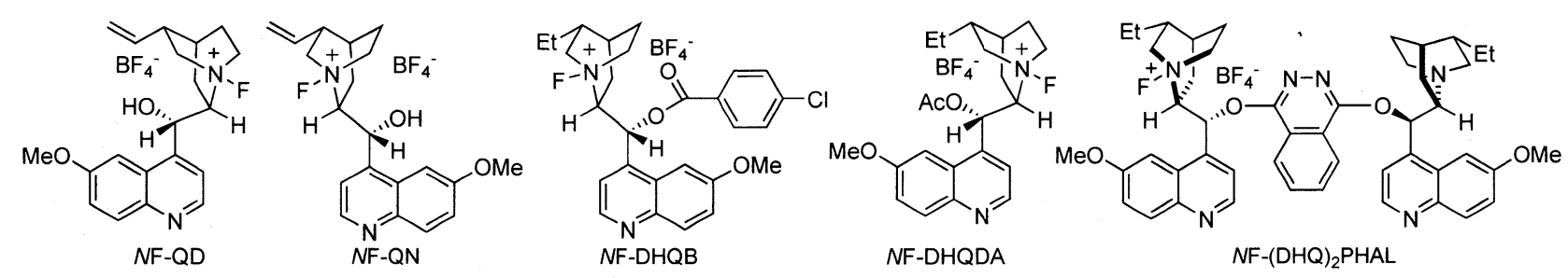

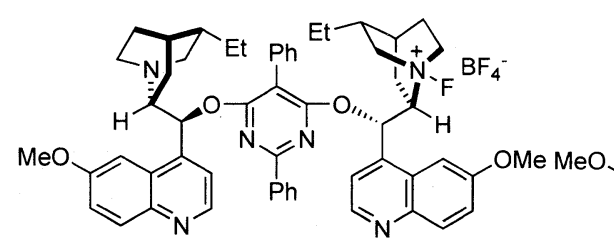

$N F-(D H Q D){ }_{2} P Y R$

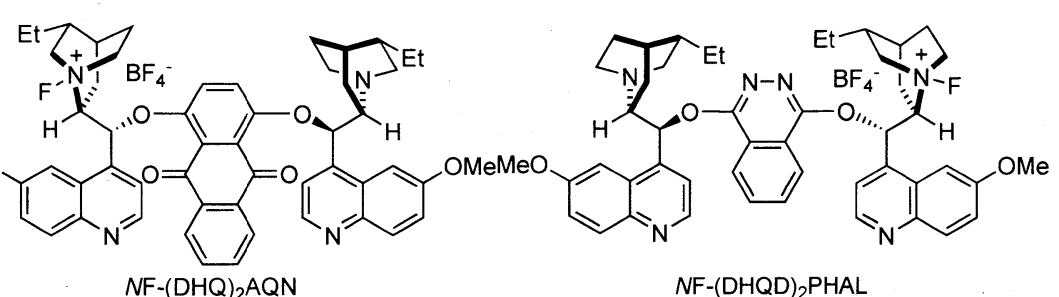

$N F-(D H Q)_{2} A Q N$
$N F-(D H Q D){ }_{2}$ PHAL

Fig. 4 Structures of $\mathrm{N}$-fluorocinchona alkaloids tetrafluoroborates. 
Table 1 Enantioselective fluorination of indanones and tetralones using $\mathrm{DHQB} /$ Selectfluor combination.

\begin{tabular}{|c|c|c|c|c|c|c|c|}
\hline \multirow[b]{3}{*}{ Entry } & \multirow{2}{*}{\multicolumn{2}{|c|}{$\int_{n}^{\mathrm{OSiMe}_{3}}$}} & \multicolumn{3}{|c|}{$\begin{array}{l}\text { DHQB/Selectfluor } \\
\text { Combination (NF-DHQB) }\end{array}$} & & $\mathrm{O}$ \\
\hline & & & & $\begin{array}{ll}\mathrm{CN} \\
\text { ver }\end{array}$ & $\begin{array}{l}-20^{\circ} \mathrm{C} \\
\text { ght }\end{array}$ & & 2 \\
\hline & 1 & $n$ & $\mathrm{R}$ & 2 & Yield (\%) & $\mathrm{Ee}(\%)$ & Config \\
\hline 1 & $1 a$ & 1 & $\mathrm{Bn}$ & $2 a$ & 99 & 89 & $R$ \\
\hline 2 & $1 b$ & 1 & $\mathrm{Me}$ & $2 b$ & 93 & 53 & $R$ \\
\hline 3 & 1c & 1 & Et & 2c & 100 & 73 & $R$ \\
\hline $4^{a}$ & $1 a$ & 1 & $\mathrm{Bn}$ & $2 a$ & 86 & 91 & $R$ \\
\hline 5 & 1d & 2 & $\mathrm{Me}$ & $2 d$ & 94 & 40 & $R$ \\
\hline $6^{b}$ & 1e & 2 & Et & $2 e$ & 71 & 67 & $R$ \\
\hline 7 & $1 f$ & 2 & $\mathrm{Bn}$ & $2 f$ & 95 & 71 & $S$ \\
\hline
\end{tabular}

a) The reation was carried out at $-40^{\circ} \mathrm{C}$ for 2 days. b) The reation was carried out at $-50^{\circ} \mathrm{C}$ in $\mathrm{MeCN} / \mathrm{CH}_{2} \mathrm{Cl}_{2}(3 / 4)$.

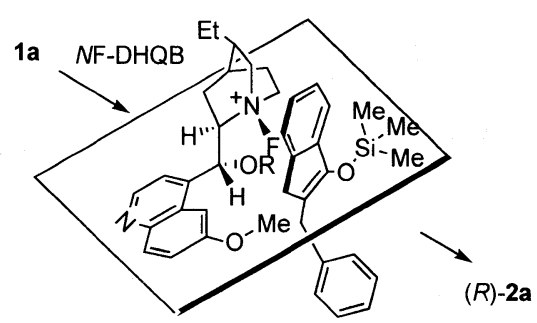

Fig. 5 Proposed transition-state assembly.

\section{3 活性水素を有する化合物への不斉フッ素化反応}

$2 つ の$ 試薬を混合するだけで簡単に調製できるキナア ルカロイド/Selectfluor ${ }^{\circledR}$ 試薬, キナアルカロイド $-N-$ フ ルオロアンモニウム塩の適用範囲は，フルオロスルタム 型試薬の場合とは比較にならないほど広い。シリルエ ノールエーテルだけでなく，活性水素を持つ鎖状，環状 化合物から生理活性の期待できるオキシインドール類の 不斉フッ素化反応にも極めて有効に作用する。しかもこ 扎らの化合物に対しては，あらかじめシリル化して活性 化して拉いたり，あるいは塩基を追加したりする必要は なく，反応基質をキナアルカロイド/Selectfluor ${ }^{\circledR}$ 試薬 と混合するだけで標的フッ素化物を首尾よく与える。ア リールシアノ酢酸エステル $3 \mathrm{a}$ に対しては, $N \mathrm{~F}-\mathrm{DHQB}$ で は不満足な結果を与えるが, ジヒドロキニジンアセテー ト (DHQDA)/Selectfluor ${ }^{\circledR}$ ，溶液から調製する $N \mathrm{~F}$ DHQDA の使用により，87\% ee でフッ素化体を与える ことがわかった。この NF-DHQDA は，アリールシア ノ酢酸エステル類全般に良好な結果を示す。いずれも, この種の反応としては格段に高い不斉収率で，対応する フルオロ体を得ることに成功した(表 2)。な抢，この DHQDA \& Sharpless 不斉ジヒドロキシル化反応に初期 の頃に使用された触媒の 1 つである。四半世紀ほども前 に設計されていた触媒の潜在能力に驚くばかりである。

$\beta$-ケトエステル類の不斉フッ素化にも NF-DHQDA が優れている。インダノン $\beta$-ケトエステル $5 \mathrm{a}$ の場合は
Table 2 Enantioselective fluorination of acyclic esters using DHQDA/Selectfluor combination.

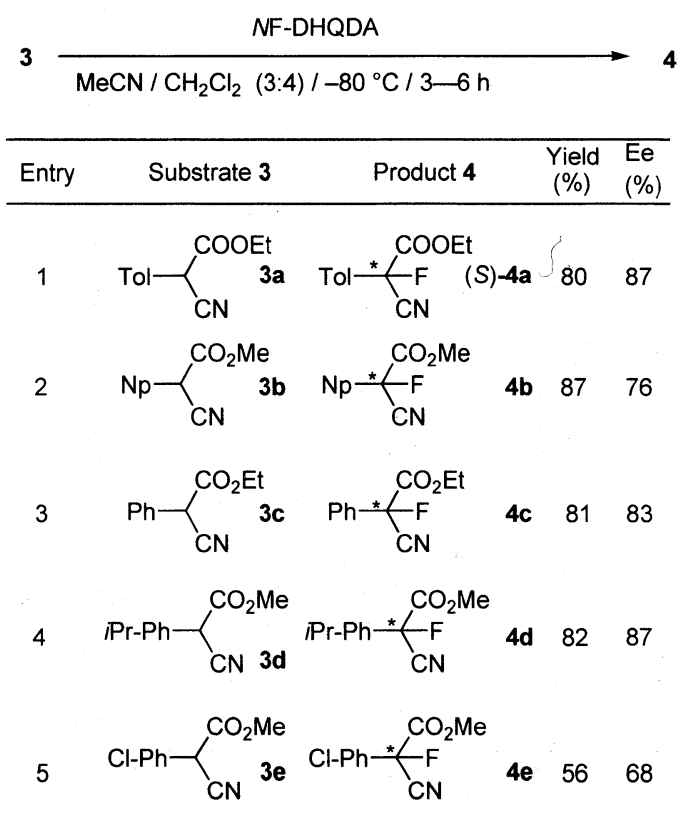

$78 \%$ ee, 5 員環上に酸素原子がある $5 \mathrm{~b}$ の場合もその影 響を受けず，80\% ee と高い不斉収率でフルオロ体 $6 \mathrm{~b}$ を得ることができた。その他の $\beta$-ケトエステルにおい ては，DHQDA では不斉収率は低いものであったが， $5 c$ の場合はジヒドロキニジン (DHQD) を用いて $59 \%$ ee で， $5 \mathrm{~d}$ の場合はジヒドロキニン $(\mathrm{DHQ})$ を用いて $43 \%$ eeでフルオロ体を得た(表 3 )。

Table 3 Enantioselective fluorination of cyclic $\beta$-keto esters.

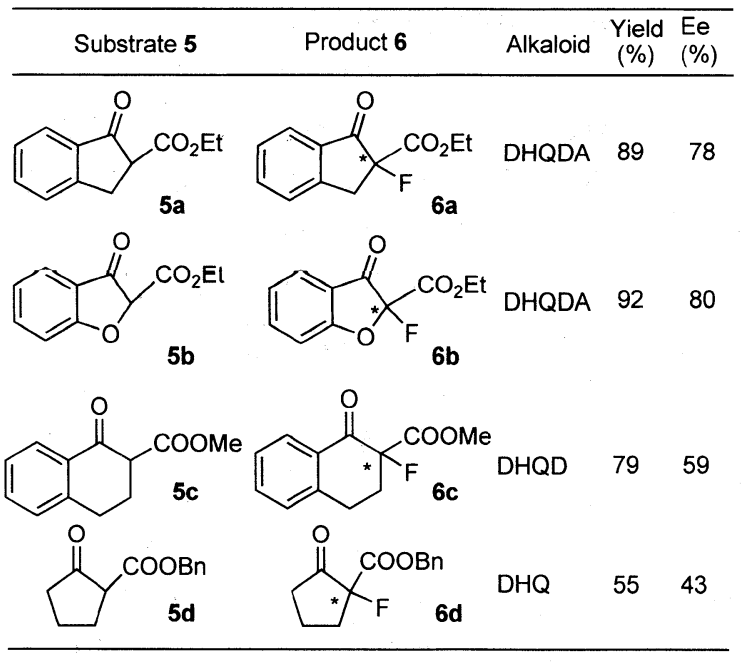

オキシインドール化合物は, 生物活性的興味から医薬 品分野において活発に研究されている。とりわけ，3 位 の水素をヒドロキシル基で置換した3-ヒドロキシオキ シインドールは, 酵素阻害荗として重要である。そこ で，オキシインドール抄よび3-ヒドロキシオキシイン ドールの疑似化合物といえる3-フルオロオキシイン 
ドールを不斉フッ素化反応により合成することとした。 この場合は, 先に結果の良かった NF-DHQB, やNFDHQDA では良い結果は得られないが，ビス構造のキナ アルカロイド, $N F-(\mathrm{DHQD}){ }_{2} \mathrm{PYR}, N \mathrm{~F}-(\mathrm{DHQ}){ }_{2} \mathrm{AQN}$ を 用いた場合に，高エナンチオ選択性で対応するフルオロ 体を与えることがわかった。3 位置換基がベンジルの場 合に最も高い不斉収率で，また，メチル，エチル基の場 合も比較的高いエナンチオ選択性で対応するフルオロ体 を与えた(表 4)。

Table 4 Enantioselective fluorination of oxindole using bis-cinchona alkaloids/Selectfluor combination.

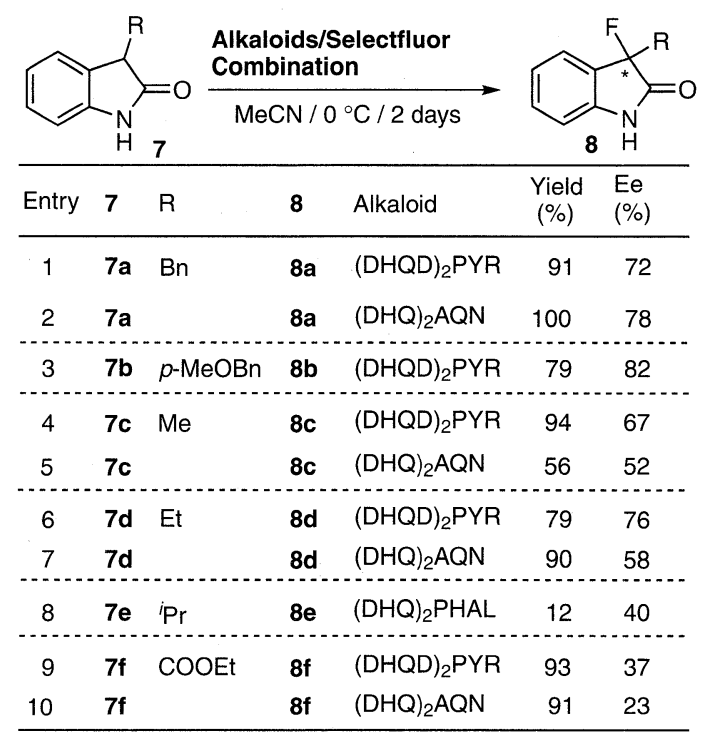

\section{2. 含フッ素生理活性物質の合成}

\section{1 虚血性脳血管治療薬 MaxiPost ${ }^{\circledR}$ の不斉合成}

強力なカリウムチャ卒ル開口作用を有する MaxiPost ${ }^{\circledR}$ は, 虚血性脳血管障害の治療薬として有望視されてい る。インドール骨格 3 位にキラル $\mathrm{C}-\mathrm{F}$ 結合を持ち, $S$ 体に強い生物活性を有するこの化合物は，フェーズ血実 施中であるにもかかわらず，不斉合成は未解決であり， その製造はラセミ体の光学分割で行われている。そこで 筆者らは $N$-フルオロアンモニウム塩試薬を活用し, MaxiPost ${ }^{\circledR}$ の不斉合成を行うこととした。まず, 先の研 究結果でキナアルカロイドのビス体である NF(DHQD) ${ }_{2} \mathrm{PYR}$ がオキシインドール類の不斉フッ素化に 有効であることがわかっていたので，これを用いてフッ 素化を行ったが，不斉収率は非常に低いものであった。 そこで，様々なキナアルカロイドを用いて本反応を検討 したところ，QD，(DHQD) ${ }_{2} \mathrm{PHAL},(\mathrm{DHQ}){ }_{2} \mathrm{PHAL}$, $(\mathrm{DHQ})_{2} \mathrm{AQN}$ を用いた場合に比較的よい結果が得られ， 特に $(\mathrm{DHQ})_{2} \mathrm{AQN}$ の使用により MaxiPost ${ }^{\circledR}$ を $84 \%$ ee で 得ることに成功した $\left(\right.$ 表 5) ${ }^{8)}$ 。また，QD を用いることに より $R$ 体を $68 \%$ ee で与えることがわかった。 $84 \%$ ee
で得られた化合物をへキサンー塩化メチレンで再結晶す ることによって, 光学純粋な MaxiPost ${ }^{\circledR}$ を得ることが できた。

Table 5 Enantioselective synthesis of MaxiPost.

\begin{tabular}{llll} 
Cinchona Alkaloid & Yield (\%) & Ee (\%) & Config. \\
\hline (DHQ) $)_{2} \mathrm{AQN}$ & 94 & 84 & $\mathrm{~S}$ \\
$(\mathrm{DHQ})_{2} \mathrm{PHAL}$ & 75 & 78 & $\mathrm{~S}$ \\
(DHQD) ${ }_{2} \mathrm{PHAL}$ & 93 & 38 & $R$ \\
$\mathrm{QD}$ & 96 & 68 & $R$ \\
\hline
\end{tabular}

The reaction was performed in $\mathrm{MeCN} / \mathrm{CH}_{2} \mathrm{Cl}_{2}$ at $-80^{\circ} \mathrm{C}$ for several hours.

ところで, MaxiPost ${ }^{\circledR} の$ 合成は，工業的製造法開発の 観点から環境問題を考慮する必要がある。そこで，この 不斉フッ素化反応をイオン液体中にて実施可能かを検討 した ${ }^{9)}$ 。残念ながらイオン液体のみではよい結果は得ら れなかったが，アセトニトリルとの混合溶媒にて $(\mathrm{DHQ})_{2} \mathrm{AQN}$ を用いた場合に比較的よい結果が得られ た。また，水とアセトニトリルやイオン液体との混合溶 媒でも反応は進行し，(DHQD) ${ }_{2} \mathrm{PHAL}$ を用いた場合に 比較的よい結果が得られた (表 6)。水/イオン液体混合 系で実施することにより, 揮発性の高い有機溶媒の使用 を回避することができる。

Table 6 Enantioselective synthesis of MaxiPost in ionic liquid, [emim] [OTf].

\begin{tabular}{|c|c|c|c|c|}
\hline Alkaloid & Solvents & Yield (\%) & $\mathrm{Ee}(\%)$ & Config \\
\hline $\begin{array}{l}\text { QD } \\
\text { QD } \\
\text { QD } \\
\text { QD } \\
\text { QD } \\
\text { QN } \\
C N \\
C D \\
(\mathrm{DHQ})_{2} \mathrm{AQN}\end{array}$ & $\begin{array}{l}{[\text { emim][OTf] }} \\
\text { MeCN/[emim][OTf] }=9 / 1 \\
\text { MeCN/[emim][OTf] }=7 / 3 \\
\text { MeCN/[emim][OTf] }=5 / 5 \\
\text { MeCN/[emim][OTf] }=3 / 7 \\
\text { MeCN/[emim][OTf] }=5 / 5 \\
\text { MeCN/[emim][OTf] }=5 / 5 \\
\text { MeCN/[emim][OTf] }=5 / 5 \\
\text { MeCN } /[\text { emim] }][O T f]=5 / 5\end{array}$ & $\begin{array}{l}84 \\
74 \\
82 \\
89 \\
81 \\
55 \\
83 \\
83 \\
99\end{array}$ & $\begin{array}{l}23 \\
39 \\
46 \\
46 \\
32 \\
35 \\
39 \\
11 \\
60\end{array}$ & $\begin{array}{l}R \\
R \\
R \\
R \\
R \\
R \\
S \\
R \\
S \\
S\end{array}$ \\
\hline $\begin{array}{l}\mathrm{QD} \\
\mathrm{QN} \\
\mathrm{CN} \\
\mathrm{CD} \\
(\mathrm{DHQ})_{2} \mathrm{AQN} \\
(\mathrm{DHQD})_{2} \mathrm{PHAl} \\
(\mathrm{DHQ})_{2} \mathrm{AQN} \\
(\mathrm{DHQD})_{2} \mathrm{PHAl} \\
\mathrm{QD} \\
\mathrm{QN} \\
\mathrm{CN} \\
\mathrm{CD}\end{array}$ & 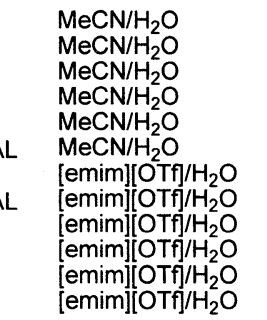 & $\begin{array}{l}95 \\
90 \\
98 \\
96 \\
99 \\
91 \\
88 \\
86 \\
85 \\
84 \\
95 \\
83\end{array}$ & $\begin{array}{c}28 \\
25 \\
13 \\
9 \\
17 \\
41 \\
2 \\
42 \\
38 \\
21 \\
30 \\
21\end{array}$ & $\begin{array}{l}R \\
S \\
R \\
S \\
S \\
S \\
S \\
S \\
R \\
S \\
S \\
R\end{array}$ \\
\hline
\end{tabular}

The reaction was performed at $0^{\circ} \mathrm{C}$ for several hours.

\section{2 光学活性 Fluorobrevianamide $\mathrm{E}$ および Fluoro- gypsetin の合成}

選択的フッ素化反応の成功を足がかりにより複雑な 分子構造を持つ生理活性物質への直接的なフッ素原子導 入反応の開発に取り掛かった。まず，生理活性天然物 brevianamide Eおよび gypsetin の疑似化合物分子の合 
成を計画した。Brevianamide E は Birch およびWright により Penicillium brevicompactum から単離された菌 類の代謝物の一種である。分子内にリバースプレニル基 を有し，トリプトファンとプロリンのジケトピペラジン 型環状ジペプチドというユニークな構造を持つため, 古 くから有機化学者の合成標的となっていた。一方 gypsetin は, Nannizzia gypsea var.incurata IFO 9928 より単離されたアルカロイドで, コレステロール やコレステロールエステルの生成を行う組織や細胞にお ける吸収に扔いて重要な働きをするアシル-CoA: コレス テロールアシルトランスフェラーゼ(ACAT)の活性を強 力に抑制するため, アテローム性動脈硬化症の予防や治 療に効果があると考えられる。

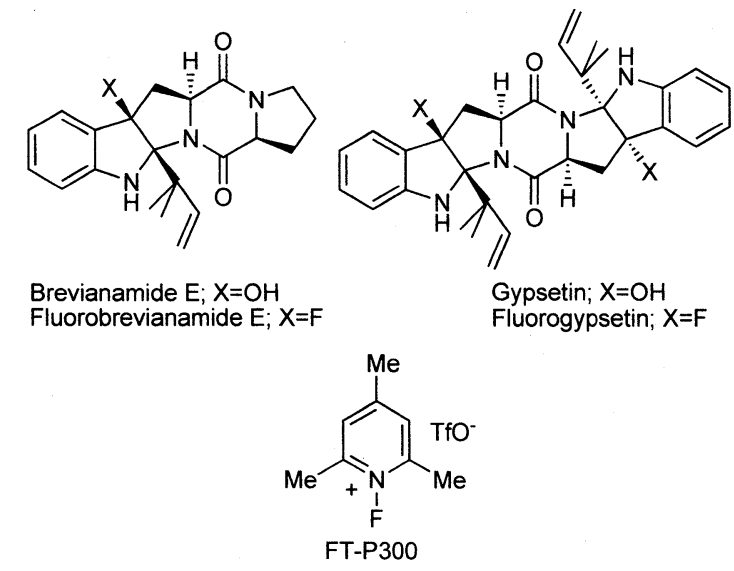

Fig. 6

Brevianamide E 㧍よび gypsetin はインドール骨格の 3 位にあたる部位に水酸基を有する。先に触れたよう に, フッ素原子は電気陰性度の点㧍よび結合距離の点か ら水酸基の絶好のミミックであるといわれている。その ため, 特に gypsetin にフッ素を導入すると, 親化合物 の薬理活性を保持したまま, 酸化耐性, 脂溶性調節など の効果が期待できるため, fluorogypsetin はアテローム 性動脈硬化症の新規予防治療薬として期待が高まる。共 通構造であるピラジノピロロインドール骨格は, 生合成 では, ジペプチドからの閉環反応に続く酸化反応で生成 すると考えられていることから, 酸化の段階をフッ素化 に置き換えた環化型フッ素化反応を開発すれば合成でき ると推測できた。なお，この場合，原料ぺプチド自身が 光学活性体であるため, 不斉フッ素化試薬を用いる必要 はない。まず，アセトニトリル中， $-40{ }^{\circ} \mathrm{C} て ゙$ Selectfluor ${ }^{\circledR}$ を用いて反応を行ったが，良い結果は得られなかった。 そこでフッ素化試薬を種々検討した結果，フルオロピリ ジニウム塩である FP-T 300 を用いて, テトラヒドロフ ラン中で加熱することにより，収率よく環化型フッ素化 反応が起こることが判明した。すなわち, deoxyprebrevianamide E をテトラヒドロフロン中, FP-T 300 で環
化的フッ素化反応を行ったところ, 反応は首尾よく進行 し, 目的の fluorobrevianamide $\mathrm{E}$ をエ゚体との混合物, ジアステレオマー比 $1: 1.6$ で得ることに成功した。同 様に, deoxypregypsetinに対しても環化的フッ素化反 応を施したところ，標的化合物 fluorogypsetin をその工 ピ体と $1: 2: 1$ の混合物, 収率 $77 \%$ で得ることに成功 した ${ }^{10)}$ 。
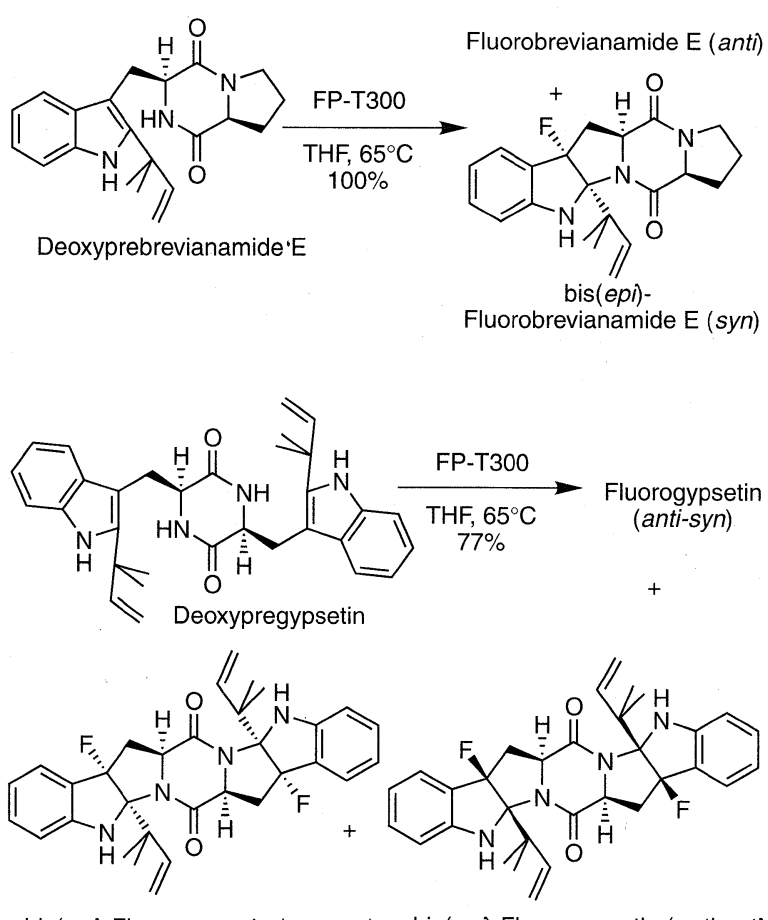

bis(epi)-Fluorogypsetin (syn-syn) bis(epi)-Fluorogypsetin (anti-anti)

Scheme 2

\section{3 フルオロカンプトテシンの設計と不斉合成}

カンプトテシン $(\mathrm{CPT})$ は, 広範囲の固形がんに高い活 性を示すという特徵を有し期待されながらも, 副作用や 溶解性の面で問題点が多く, 理想の抗がん剂とはいえな い。そこで分子内に唯一存在する不斉炭素に注目し，そ の水酸基をフッ素に置換したフルオロカンプトテシン （FluoroCPT）を設計した。カンプトテシンは，生体内で 加水分解されラクトン部位が開環することが知られてい る。開環した化合物の抗腫掦活性は低く, 薬効低下の要 因の 1 つに挙げられる。この開環反応は, 不斉中心に位 置する水酸基とラクトンカルボニル部位との分子内水素 結合により促進されると考えられ，水酸基をフッ素で置 き換えることとした(図 7)。水酸基は水素供与基㧍よび 受容基としての両機能を持つが，フッ素は，弱い受容基 としてのみ作用する。そのため, フッ素を導入した FluoroCPT は, 分子内水素結合を抑え, かつ, 水素受 容部位としての機能を保持する可能性が高く, カンプト テシン擬似分子として非常に魅力的である。加えて, フッ素原子に起因する酸化耐性拉よび脂溶性を変化させ る効果により, 細胞膜透過性拉よび生体利用率向上も 
<smiles>CC[C@@]12C=C3c4nc5ccccc5cc4CN3C(=O)C1COC2=O</smiles>
(CPT)

1

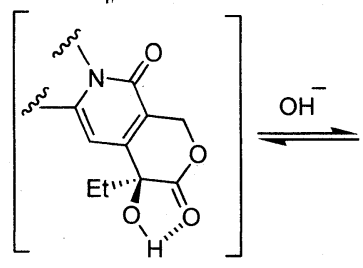

Camptothecin

Fig. 7
20-Deoxy-20-fluorocamptothecin (20(S)-FluoroCPT)

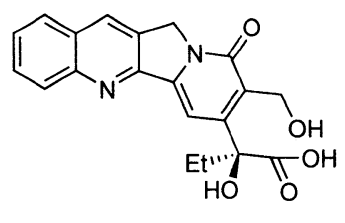

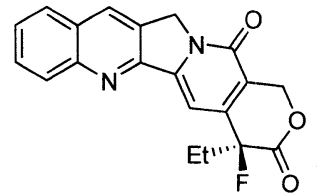

期待できる。

20-デオキシカンプトテシン (20-DeoxyCPT)に対し，

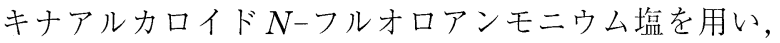
不斉フッ素化反応を試みた。キナアルカロイド誘導体お よび反応溶媒をスクリーニングした結果, $N F-(\mathrm{DHQ})_{2}$ PHAL を塩化メチレン中で用いることにより，標的化合 物 $(S)$-FluoroCPTを $81 \%$ ee で得ることに成功した。 また，NF-(DHQD) ${ }_{2} \mathrm{PHAL} の$ 使用により，鏡像異性体 である $(R)$-FluoroCPT を 88\% ee で得ることができた11)。<smiles>CCC1C(=O)OCc2c1cc1n(c2=O)Cc2cc3ccccc3nc2-1</smiles>

20-Deoxycamptothecin

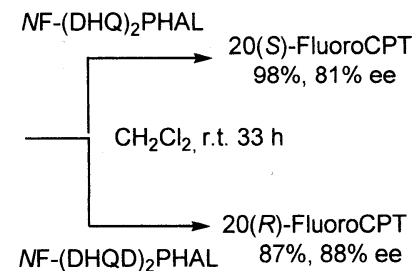

Scheme 3

\section{3. フルオラスキナアルカロイドの合成と不斉フッ素 化反応}

フルオロカーボンは，有機溶媒とは混和しないため両 者を混合すると二相となるが，加熱により一相となり， 冷却すれば再び二相に戻る特徵を持つ。この性質を利用 すれば，環境調和型の有機合成反応を生み出すことが可 能となる。フルオラス二相システムと呼ばれるこの新技 術は，イオン液体を用いる反応や水中反応と並んで，環 境に優しい有機合成反応として注目されている ${ }^{12)}$ 。その ためフルオロカーボン相にのみ溶解する触媒の開発が重 要となってきた。筆者らは, キナアルカロイドをフルオ ラス化することを計画した。フルオラス化したキナアル カロイドは, 高濃度でフルオラス溶媒に溶かし込むこと ができ，かつ通常の有機溶媒とは混和しないため，フル オロカーボン溶媒やフルオラスカラムなどで容易に回収 できると考えられる。

キナアルカロイドとしては DHQB を選択した。DHQB
は，Sharpless 不斉酸化反応をはじめ，様々な不斉反応 に実績をもつ重要な化合物である。フルオラス型 DHQB (Fluorous-DHQB) が合成できれば，当該不斉 フッ素化反応だけでなく, 様々な不斉反応をフルオラス 反応化できる可能性が高い。分子の設計は，市販品の試 薬にて簡便に合成できることを重要と考え, 図 8 のよう な構造を創出した。

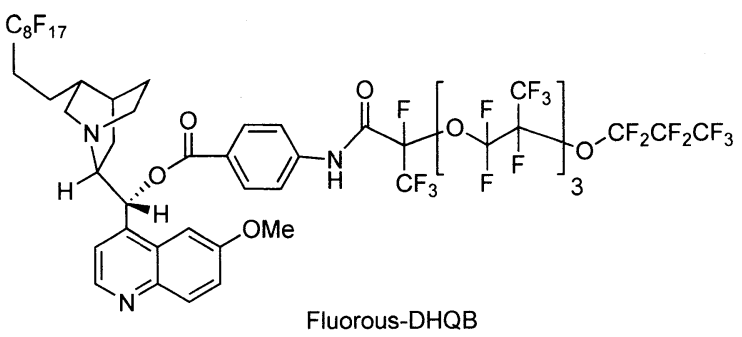

Fig. 8

まず，ペルフルオロオクチルキニン (Fluorous-DHQ) の水酸基を, 塩化パラスルフィニルアミノベンゾイルを 用いて， $p$ アアミノベンゾイル化した。生じた末端アミ ノ基を足がかりに，テトラヒドロフラン中，トリエチル アミンの存在下, perfluoro $(2,5,8,11$-tetramethyl3, 6, 9, 12-tetraoxa-pentadecanoyl) fluoride にてフルオ ラス鎖を導入し，Fluorous-DHQB を合成した。この Fluorous-DHQB のフッ素含有率は約 $52 \%$ でり，フル オラス能力を発揮するには不十分な值ではあるものの, 各種有機溶媒への溶解性を調べたところ, 非極性有機溶 媒での抽出により比較的高い割合でフルオラス相に溶解 することがわかった(表 7)。

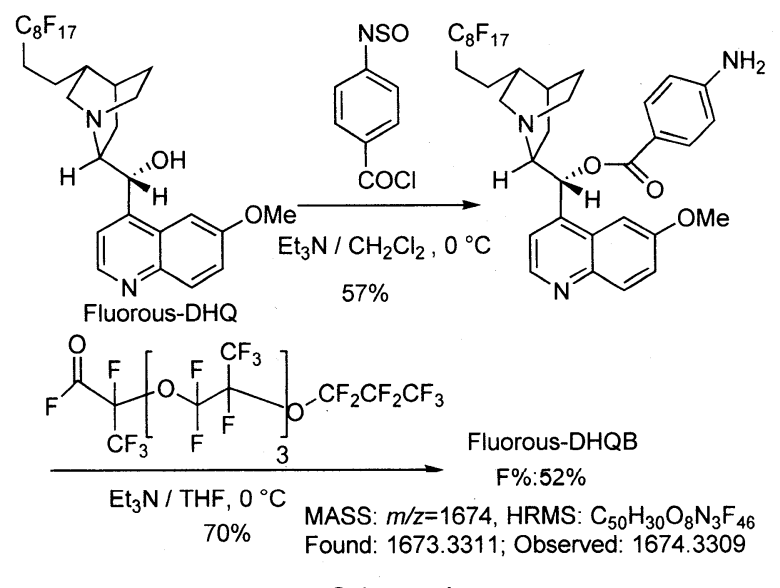

Scheme 4

Table 7 Partition coefficients of fluorous-DHQB.

\begin{tabular}{ccc}
\hline Solvent & Temp $\left({ }^{\circ} \mathrm{C}\right)$ & Distribution \\
\hline Toluene $/ c-\mathrm{C}_{6} \mathrm{~F}_{11} \mathrm{CF}_{3}$ & 25 & $1 / 4$ \\
\hline Hexane $/ \mathrm{c}-\mathrm{C}_{6} \mathrm{~F}_{11} \mathrm{CF}_{3}$ & 0 & $1 / 10$ \\
$\mathrm{MeCN} / \mathrm{c}-\mathrm{C}_{6} \mathrm{~F}_{11} \mathrm{CF}_{3}$ & 25 & mixture \\
\end{tabular}


Fluorous-DHQB/Selectfluor ${ }^{\circledR}$ 試薬を用いてシリルエ ノールエーテルの不斉フッ素化反応を行った。すなわ ち，1aをフルオラス相に溶かし込んだ Fluorous-DHQB/ Selectfluor ${ }^{\circledR}$ 試薬と処理したところ，収率よく，2a を高 い光学純度で得ることに成功した ${ }^{13)}($ スキーム 5)。

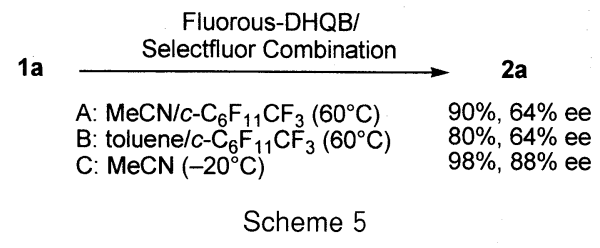

\section{4. 両鏡像異性体の作り分けを可能にする柔軟性の高 い不斉フッ素化反応}

\subsection{Box-Ph 触媒を用いる $\beta$-ケトエステル類の触 媒的不斉フッ素化反応}

キナアルカロイド/Selectfluor ${ }^{\circledR}$ 試薬は, シリルエ ノールエーテル類, $\beta$-ケトエステル類, アリールシア ノ酢酸エステル類, オキシインドール類，ケトン類 ${ }^{5)}$, ペプチド5)，アリルシラン類 ${ }^{14)}$ およびラクトン化合物な ど，広範囲な基質に対して有効性を示す初めての不斉 フッ素化試薬であり, その実用性の高さは生理活性物質 合成において実証された。また，キナアルカロイドをフ ルオラス化することにより試薬の回収を容易にすること ができた。しかし，試薬という性格上，キナアルカロイ ドを化学量論量使用する必要がある。筆者らがこの研究

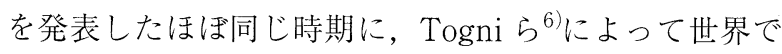
初めての触媒的不斉フッ素化反応が報告された。彼らは Selectfluor ${ }^{\circledR}$ を用いる $\beta$-ケトエステルのフッ素化反応に おいて, チタン/酒石酸誘導体を触媒に用いることによ り，二点配位型の錯体を経由し，高エナンチ才選択性で フッ素化体が得られることを見出した。この時点でのエ ナンチオ選択性については，まだ改善の余地が残されて いたが，その後このアプローチは袖岡らの Pd 錯体を用 いる方法 ${ }^{15)} に よ り$ 劇的に改善された。鎖状構造から環状 構造までバリエーションに富んだ $\beta$-ケトエステル類の 不斉フッ素化反応を，すべて $90 \%$ ee 以上の選択性で実 現した袖岡らの方法は，この分野を一挙に完成にまで近 づけた16)。

袖岡らの研究成果に刺激され，筆者らは，もう一歩踏 み达んだ新しいフッ素化反応ができないものかと模索し 始めていた。当時, 筆者らの研究室では, フッ素化反応 の開発研究とは別に, キラルなビスオキサゾリン型触媒 (Box 触媒) を用いた様々な不斉反応の開発研究を展開し ていた ${ }^{17)}$ ○アミノ酸より簡便に合成できるビスオキサゾ リン触媒は, 世界中で汎用されるキラル触媒の1つで, キナアルカロイドと同じく，その不斉合成の実績は大き い。そこで筆者らは，この触媒を活用した新しいフッ素
化反応の開発を目指すこととした。着手してまもなく， $\beta$-ケトエステル類の触媒的不斉フッ素化反応において, 添加する金属塩の種類を $\mathrm{Cu}(\mathrm{II})$ あるいは $\mathrm{Ni}(\mathrm{II})$ と使い 分けるだけで, 同じ不斉源から両鏡像異性体を作り分け るという興味深い現象に遭遇した ${ }^{18)}($ スキーム 6)。

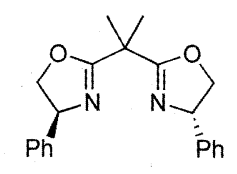

(S,S)-Bis(oxazoline)-Ph (Box-Ph)

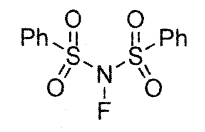

$N$-Fluorobenzenesulfonimide (NFSI)

(S)-isomer up to $84 \%$ ee

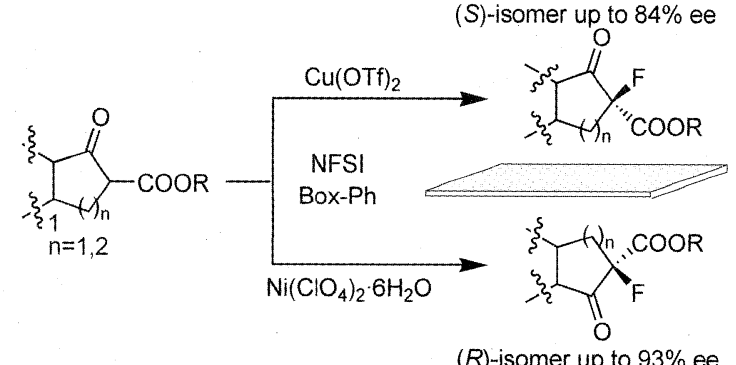

Scheme 6

反応は次のように実施した。 0.1 当量のビスオキサゾ リンフェニル触媒 $(\mathrm{Box}-\mathrm{Ph})$ に $\mathrm{Cu}(\mathrm{OTf})_{2}$ あるいは $\mathrm{Ni}^{-}$ $\left(\mathrm{ClO}_{4}\right)_{2} \cdot 6 \mathrm{H}_{2} \mathrm{O}$ を 0.1 当量ずつ混合した後, 塩化メチレ ン, エーテル，テトラヒドロフランあるいは $t$-ブチル メチルエーテルなどの溶液とした。そこに $\beta$-ケトエス テル類，N-フルオロベンゼンスルホンイミド(NFSI)を 加え, 一昼夜擋拌後, 処理してフッ素化体の不斉収率を 求めた。インダノン型, テトラロン型, あるいはシクロ ペンタノン型の $\beta$-ケトエステル類に対する不斉フッ素 化を行ったところ，基質の基本骨格の影響を大きく受け ることなく, $\mathrm{Cu}(\mathrm{OTf})_{2}$ の場合には，S 体のフッ素化体 を, $\mathrm{Ni}\left(\mathrm{ClO}_{4}\right)_{2} \cdot 6 \mathrm{H}_{2} \mathrm{O}$ を添加した場合には $R$ 異性体を優 先して与えることがわかった。基質によってはモレキュ ラーシーブズの添加が効果的な場合もあり，最高で 93\% ee を示した(スキーム 7)。なお，エステル部位に かさ高い置換基である tert-ブチル基，1-アダマンチル 基を用いることが必須であり，エチル基，シクロへキシ ル基を用いた場合には，選択性の逆転現象は観察される ものの満足できる不斉収率は得られない。一方，鎖状構 造の $\beta$-ケトエステル類に対しては，収率，選択性とも に低く，金属触媒を变更しても生成物の立体化学は逆転 しないなど課題は残った。また，不思議なことに $\beta$-ケト リン酸エステルの場合も，金属触媒による立体化学の反 転現象は見られなかった(表 8)。このように適応範囲は 限定されるが，1つの不斉源より，両鏡像異性体を作り 分けた意義は大きい。なお，偶然にもビスオキサゾリン 触媒 Box-Ph および Box- $t$ Bu を用いた不斉フッ素化, 塩 素化，臭素化がほほ同時期にCahard $5^{19)}$ ，Jørgensen 

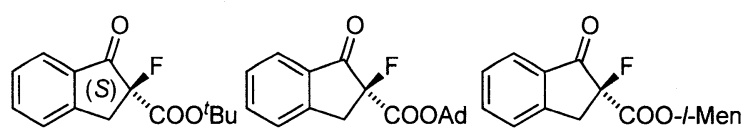

(S)-9 (81\%, 70\% ee) (S)-10 (79\%, 84\% ee) (S)-11 (86\%, 55\% de) (R) -9 ( $87 \%, 93 \%$ ee) $(R)-10(74 \%, 79 \%$ ee) $(R)-11(95 \%, 77 \%$ de $)$
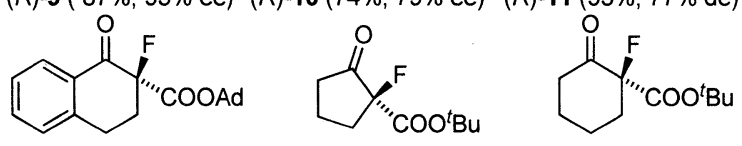

(S)-12 (73\%, 72\% ee) (S)-13 (83\%, 71\% ee) (S)-14 (84\%, 62\% ee) $\begin{array}{ll}(S)-12(73 \%, 72 \% \text { ee }) & (S)-13(83 \%, 71 \% \text { ee }) \\ (R)-12(85 \%, 17 \% \text { ee }) & (R)-13(72 \%, 67 \% \text { ee })(R)-14(84 \%, 62 \% \text { ee }) \\ (R-14 \% \text { ee })\end{array}$

Scheme 7 Enantioselective fluorination reaction catalyzed by $\mathrm{Box}-\mathrm{Ph} / \mathrm{Cu}$ (II) (first line) or Box- $\mathrm{Ph} / \mathrm{Ni}$ (II) ( $\mathrm{sec}^{-}$ ond line).

Table 8 Box-Ph/Metal(II) catalyzed enantioselective fluorination reaction.

\begin{tabular}{|c|c|c|c|c|}
\hline Metal Catalyst & Solvent & Product & Yeild (\%) & $\mathrm{Ee}(\%)$ \\
\hline $\mathrm{Cu}(\mathrm{OTf})_{2}$ & ${ }^{t} \mathrm{BuOMe}$ & & 83 & $20(+)$ \\
\hline $\mathrm{Ni}\left(\mathrm{ClO}_{4}\right)_{2} / 6 \mathrm{H}_{2} \mathrm{O}$ & $\mathrm{CH}_{2} \mathrm{Cl}_{2}$ & & 94 & $40(+)$ \\
\hline $\mathrm{Cu}(\mathrm{OTf})_{2}$ & ${ }^{t} \mathrm{BuOMe}$ & & & $60(+)$ \\
\hline $\mathrm{Ni}\left(\mathrm{ClO}_{4}\right)_{2} / 6 \mathrm{H}_{2} \mathrm{O}$ & THF & & 34 & $61(+)$ \\
\hline
\end{tabular}

$ら^{20}$ によっても報告されたが，鏡像異性体の作り分けは 見出していない。

反応機構は次のように説明することができる。 $\mathrm{Cu}^{-}$ (II)の幾何構造は，配位子の種類や反応条件などで微妙 に変化することが知られている。Evansらは Box$\mathrm{Ph} / \mathrm{Cu}$ (II) 錯体中の $\mathrm{Cu}(\mathrm{II})$ の幾何構造が歪んだ正方形型で あることをX線結晶構造解析により明らかにしている21)。 ここでも $\mathrm{Cu}(\mathrm{II})$ が歪んだ正方形型であると仮定すると， 図 9 に示したような中間体を形成すると考えられる。そ こで NFSI は，Box-PhのPh 基によって遮蔽されてい る $R e$ 面ではなく, 空間のできた $S i$ 面から接近して $S$ 体のフッ素化合物を選択的に与えたと考えられる。一 方，Box-Ph/Ni(II)錯体は，これまでには調べられた形 跡はないが, Evans らの Box- $t \mathrm{Bu} / \mathrm{Ni}$ (II) 錯体の X 線結 晶構造解析 ${ }^{22}$ ，金政らの $\mathrm{DBFOX} / \mathrm{Ni}(\mathrm{II})$ 錯体 ${ }^{23)}$ を参考に 考察すると，筆者らの $\mathrm{Box}-\mathrm{Ph} / \mathrm{Ni}$ (II)/水和物錯体にお ける $\mathrm{Ni}$ (II) の幾何構造は正方錐型であると推定できる。 これにより図 9 に示す中間体を形成し，空間のできた $R e$ 面からの攻撃により $R$ 体を選択的に与えたと考えら れる。

\subsection{Box-Inda 触媒を用いる $\beta$-ケトエステル類の触 媒的不斉フッ素化反応}

配位金属の幾何構造がエナンチオ面選択に大きく影響 する。そこで，金属幾何構造変化をより厳密に制御する ことができれば，不斉収率向上が期待できる。Sibi ら は，Box-Inda-Cp を使用した不斉反応において，高い 不斉誘起を実現している ${ }^{24)}$ が，その理由の 1 つに,

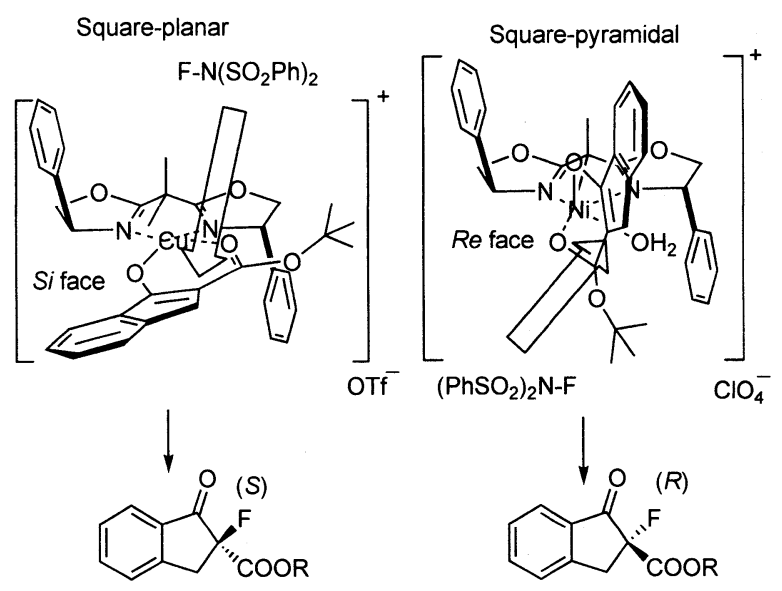

Fig. 9
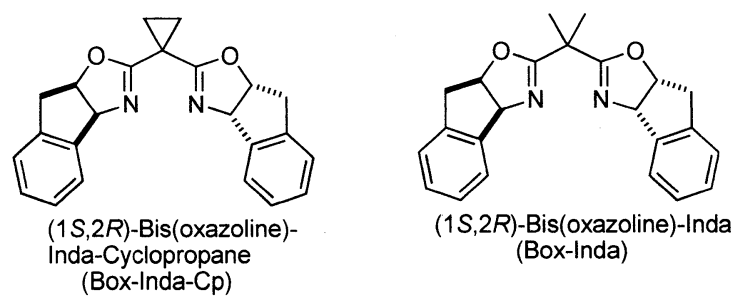

Fig. 10

Box-Inda-Cp のシクロプロパン環の影響による金属の 幾何構造の変化を指摘している。

そこで筆者らは，不斉収率の向上を念頭に，BoxInda 系触媒を用いて本反応を行うこととした（図 10）。 その結果，不斉収率向上は見られなかったが，面選択性 に扔いては, Box-Ph 触媒とは逆の結果を与えることを 観察した ${ }^{25)}$ 。すなわち, $\mathrm{Cu}(\mathrm{OTf})_{2}$ 存在下, Box-Inda あるいは Box-Inda-Cp 触媒を用いて行ったところ，不 斉収率に関しては改善される場合と低下する場合がある など変動した値を示したが，不思議なことにすべての例 において，Box-Ph を用いた場合とは生成物の絶対配置 が逆転していた。この現象は $\mathrm{Cu}$ (II)を用いた場合だけ でなく, $\mathrm{Ni}\left(\mathrm{ClO}_{4}\right)_{2} / 6 \mathrm{H}_{2} \mathrm{O}$ 触媒下での反応に执いても同 様に見られた。つまり，Box-Ph 触媒の場合では， $\mathrm{Cu}-$ (II) 存在下で $S$ 異性体, $\mathrm{Ni}$ (II) 存在下で $R$ 異性体を与 えるのに対し, Box-Inda 系触媒では, $\mathrm{Cu}(\mathrm{II})$ 存在下で $R$ 異性体, $\mathrm{Ni}$ (II) 存在下で $S$ 異性体を与えるということ である(スキーム 8)。Box-Ph, Box-Inda とも絶対配置 は同じであることを考えると，架橋部位の有無により生 成物の絶対配置が逆転する結果は興味深い。Box 触媒の 置換基の種類を変更することで生成物の絶対構造が逆転 する現象は，様々な不斉反応中で報告されているが26)， 反応機構の詳細については不明な点が多い。特に Ni（II）を使用した場合の報告例はほとんどないため，今 後，錯体の X 線結晶構造解析を通じて反応機構の詳細を 明らかにしたいと考えている。 


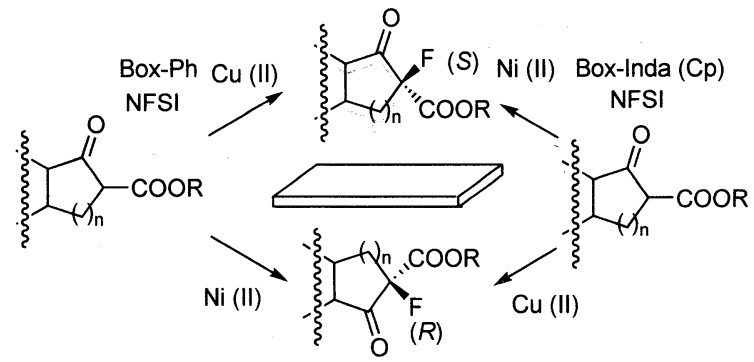

Box-Inda-Cp/Cu

$\mathrm{Box}-$ Inda/Cu

Box-Inda-Cp/Ni

Box-Inda/Ni

$(R)-9 ; 72 \%$ ee $(R)-10 ; 67 \%$ ee $(R)-12 ; 82 \%$ ee (R)-9; $31 \%$ ee $\quad(R)-10 ; 39 \%$ ee $(R)-12 ; 72 \%$ ee

(S) $-9 ; 40 \%$ ee (S) $-10 ; 49 \%$ ee (S)-12; $16 \%$ ee $\begin{array}{lll}\text { (S) }-9 ; 64 \% \text { ee } & \text { (S) }-10 ; 66 \% \text { ee }(S)-12 ; 65 \% \text { ee }\end{array}$

Scheme 8 Enantioselective fluorination reaction catalyzed by Box-Inda-Cp or Box-Inda.

\section{おわりに}

以上，筆者らが行ってきた不斉フッ素化反応に関する 研究を中心に紹介してきた。本法のほとんどが特別な装 置や技術を必要とせず，市販試薬だけで実施できるとい う特徵を持ち, 生理活性物質合成へと応用できる。フル オロアンモニウム塩法およびビスオキサゾリン法とも に，種々の問題点が残っており未完成ではあるものの， いずれ工業スケールで実施できる実用的反応に成長して 欲しいと願っている。今回, 不斉フッ素化反応に抜群の 効果を発揮したキナアルカロイド誘導体は，すべて過去 に合成されていたものであり，その化学構造自体に筆者 らのオリジナリティーはない。ビスオキサゾリン型触媒 についても同様である。良く知られた試薬との組み合わ せから興味深い不斉フッ素化反応が生まれた今回の研究 を通じて，古くから使用されてきた試薬の潜在能力にあ らためて感動するとともに，キナアルカロイドやキラル ビスオキサゾリジン化合物を初めて紹介した化学者らの 偉大さを，今さらながら再認識するばかりである。筆者 らのキナアルカロイドを用いた研究は, その後, 不斉ス ルフィニル化反応として ${ }^{27)}$ ，また，Box-Ph 触媒を用い た反応は DBFOX 触媒を用いたフッ素化および塩素化反 応として継続しており ${ }^{28)}$ ，別の機会に紹介したい。現 在, 不斉フッ素化反応の開発研究には多くの研究者が参 入し，世界の至る所から多様で，すばらしいアイデアが どんどん登場してくる現状にある。とりわけ，最近の新 潮流の 1 つであるプロリン型有機触媒を用いる研究者ら が不斉フッ素化に着目したこともあり，その研究領域は さらなる新展開を見せている29)。

謝辞 本稿で紹介した研究成果は，すべて名古屋工業大 学および富山医科薬科大学において行われたものであ り，ご指導を賜りました名古屋工業大学大学院工科学研 究科融健教授, 中村修一博士, 桑原恭子技官, 富山医科 薬科大学薬学部竹内義雄教授, 高橋たみ子助教授 (現城 西国際大学薬学部教授)に深く感謝いたします。また,
X 線結晶構造解析にご協力いただきました早稲田大学生 命医療工学研究所理工学研究科朝日透教授, 理学電機城 始勇博士，ビスオキサゾリジン触媒に関しましてご助言 をいただきました九州大学大学院総合理工学府金政修司 教授に感謝いたします。また，[emim][OTf]はセント ラル硝子株式会社, FP-T 300 は東ソー・エフテック株 式会社, カンプトテシンは株式会社ヤクルト本社, BoxInda の原料は株式会社ケミクレア様からご提供いた だきました。本稿で紹介した研究成果は, 文献に記載し た多くの共同研究者, 学部学生, 大学院学生諸氏の絶え 間ない努力によって得られたものであります。特に，日 夜実験に献身的に取り組んでいただいた鈴木英美子氏， 樽井隆直氏，石丸剛久氏，河野順二氏，水田賢志氏，中 村真衣氏，永井達矢氏らの協力なしには発見できないも のでありました。この場を借りて深く感謝申し上げま す。本研究の一部は文部科学省研究費補助金, 上原記念 生命科学振興財団, 武田科学振興財団, 公益信託三菱化 学研究奨励基金, 立松財団, 独立行政法人科学技術振興 機構 (JST) プラザ東海からご支援いただいたことに，深 くお礼申し上げます。また，本研究の一部は 2000 年度 有機合成化学協会武田薬品工業研究企画賞の企画を実現 させたものでもあります。

最後に，折に触机筆者の研究生活を支えて下さいまし た相模中央化学研究所所長(現顧問)寺島孜郎先生, 富山 医科薬科大学副学長 (現名誉教授) 竹口紀晃先生に心から 感謝の意を表します。

(2005 年 7 月 13 日受理)

文 献

1）小林義郎，熊懁棱丸，田口武夫編集: “フッ素薬学，基礎と実 験”，廣川書店, 1993

2）田口武夫，松村靖，森澤義富，“フッ素化学入門”，日本学術 振興会・フッ素化学第 155 委員会編, 三井出版, 2004, p 395

3) E. Differding, R. W. Lang, Tetrahedron Lett., 29, 6087 (1988)

4）総説抒よびその引用文献を参照：(a) F. A. Davis, H. Qi, G. Sundarababu, "In Enantiocontrolled Synthesis of Fluoroorganic Compounds" ed. by V. A. Soloshonok, John Wiley \&t Sons Ltd.: Chichester, 1999, pp 1-32; (b) G. G. Furin, A. A. Fainzilberg, Russian Chem. Rev., 68, 653 (1999); (c) S. D. Taylor, C. C. Kotoris, G. Hum, Tetrahedron, 55, 12431 (1999); (d) K, Muniz, Angew. Chem. Int. Ed., 40, 1653 (2001); (e) H. Ibrahim, A. Togni, Chem. Commun., 2004, 1147; (f) J. A. Ma, D. Cahard, Chem. Rev., 104, 6119 (2004)

5) (a) D. Cahard, C. Audouard, J.-C. Plaquevent, N. Roques, Org. Lett., 2, 3699 (2000); (b) D. Cahard, C. Audouard, J.-C, Plaquevent, L. Toupet, N. Roques, Tetrahedron Lett., 42, 1867 (2001); (c) B. Mohar, J. Baudoux, J.-C. Plaquevent, D. Cahard, Angew. Chem. Int. Ed., 40, 4214 (2001); (d) C. Baudequin, J.-C, Plaquevent, C. Audouard, D. Cahard, Green Chem., 4, 584 (2002); B. Mohar, D. Sterk, L. Ferron D. Cahard, Tetrahedron Lett., 46, 5029 (2005)

6) (a) L. Hintermann, A. Togni, Angew. Chem. Int. Ed., 39, 4359 (2000); (b) S. Piana, I. Devillers, A. Togni, U. Rothlisberger, ibid., 41, 979 (2002); (c) A. Togni, A. Mezzetti, P. Barthazy, C. Becker, I. Devillers, R. Frantz, L. Hintermann, M. Perseghini, M. Sanna, Chimia, 55, 801 (2000) 
7) (a) N. Shibata, E. Suzuki, Y. Takeuchi, J. Am. Chem. Soc., 122, 10728 (2000); (b) N. Shibata, E. Suzuki, T. Asahi, M. Shiro, ibid., 123, 7001 (2001); (c) 柴田哲男, ファルマシア, 39, 666 (2003)

8) N. Shibata, T. Ishimaru, E. Suzuki, K. L. Kirk, J. Org. Chem., 68, 2494 (2003)

9）(a）石丸剛久, 鈴木英美子，柴田哲男，平成 14 年度有機合成 化学北陸セミナ一要旨集, P-6 (2002, 福井); (b) 柴田哲男, 石 丸剛久, 水田賢志, 鈴木英美子, 第 26 回フッ素化学討論会要 旨集, 10-15 (2002, 福井)

10) N. Shibata, T. Tarui, Y. Doi, K. L. Kirk, Angew. Chem. Int. Ed., 40, 4461 (2001)

11) N. Shibata, T. Ishimaru, M. Nakamura, T. Toru, Synlett, 2004, 2509

12）総説掞よびその引用文献を参照: J. A. Gladysz, D. P. Curran, Tetrahedron, 58, 3823 (2002)

13）水田賢志, 柴田哲男, 平成 14 年度有機合成化学北陸セミナー 要旨集, P-7 (2002, 福井)

14) B. Greedy, J.-M. Paris, T. Vidal, V. Gouverneur, Angew. Chem. Int. Ed., 42, 3291 (2003)

15) Y. Hamashima, K. Yagi, H. Takano, L. Tamas, M. Sodeoka, J. Am. Chem. Soc., 124, 14530 (2002)

16）袖岡らの手法は収率，不斉収率，基質一般性および反応バリ エーションのいずれの点に执いても，最も優れた不斉フッ素 化法へと成長している。(a) Y. Hamashima, H. Takano, D. Hotta, M. Sodeoka, Org. Lett., 5, 3225 (2003); (b) 濱島義隆, 袖岡幹子,.ファルマシア, 40, 507 (2004); (c) Y. Hamashima, T. Suzuki, Y. Shimura, T. Shimizu, N. Umebayashi, T. Tamura, N. Sasamoto, M. Sodeoka, Tetrahedron Lett., 46, 1447 (2005); (d) H. R. Kim, D. Y. Kim, ibid., 46, 3115 (2005); (e) Y. Hamashima, T. Suzuki, H. Takano, Y. Shimura, M. Sodeoka, J. Am. Chem. Soc. 127, 10164 (2005)

17) 例えば (a) S. Nakamura, R. Nakagawa, Y. Watanabe, T. Toru, J. Am. Chem. Soc., 122, 1340 (2000); (b) idem, Angew. Chem. Int. Ed., 39, 353 (2000)

18）(a) 永井達矢, 石丸剛久, 柴田哲男, 融健, 第 27 回フッ素化 学討論会要旨集, 1 P-27 (2003, 長野); (b) N. Shibata, T. Ishimaru, T. Nagai, J. Kohno, T. Toru, Synlett, 2004, 1703

19) J.-A, Ma, D. Cahard, Tetrahedron: Asymmetry, 15, 1007 (2004)

20) M. Marigo, N. Kumaragurubaran, K. A. Jørgensen, Chem. Eur. J., 10, $2133(2004)$

21) (a) D. A. Evans, J. S. Johnson, C. S. Burgey, C. R. Campos, Tetrahedron Lett., 40, 2879 (1999); (b) D. A. Evan, J. S. John- son, E. J. Olhava, J. Am. Chem. Soc., 122, 1635 (2000); (c) J. Thorhauge, M. Roberson, R. G. Hazell, K. A. Jørgensen, Chem. Eur. J., 8, 1888 (2002)

22) D. A. Evans, C. W. Downey, J. L. Hubbs, J. Am. Chem. Soc., 125, 8706 (2003)

23) (a) K. Itoh, S. Kanemasa, J. Am. Chem. Soc., 124, 13394 (2002); (b) S. Kanemasa, Y. Oderaotoshi, J. Tanaka, E. Wada, ibid., 120, 12355 (1998)

24）例えば (a) M. P. Sibi, J. J. Shay, M. Liu, C. P. Jasperse, J. Am. Chem. Soc., 120, 6615 (1998); (b) M. P. Sibi, J. Chen, ibid., 123, $9472(2001)$

25）石丸剛久, 河野順二, 高井和美, 島津圭佑, 柴田哲男, 融健, 金政修司，第 28 回フッ素化学討論会要旨集，1 P-32 (2004, 神奈川)

26）例えば (a) M. P. Sibi, J. Ji, J. Org. Chem., 62, 3800 (1997); (b) M. P. Sibi, H. Matsunaga, Tetrahedron Lett., 45, 5925 (2004)

27) N. Shibata, M. Matsunaga, M. Nakagawa, T. Fukuzumi, S. Nakamura, T. Toru, J. Am. Chem. Soc., 127, 1374 (2005)

28) N. Shibata, J. Kohno, K. Takai, T. Ishimaru, S. Nakamura, T. Toru, S. Kanemasa, Angew. Chem. Int. Ed., 44, 4204 (2005)

29）例えば(a) D. Enders, M. R. M. Hüttl, Synlett, 2005, 991; (b) M. Marigo, D. Fielenbach, A. Braunton, A. Kjarsgaard, K. A. Jørgensen, Angew. Chem. Int. Ed., 44, 3703 (2005); (c) D. D. Steiner, N. Mase, C. F. III. Barbas, ibid., 44, 3706 (2005); (d) T. D. Beeson, D. W. C. MacMillan, J. Am. Chem. Soc., 127, $8826(2005)$

\section{PROFILE}

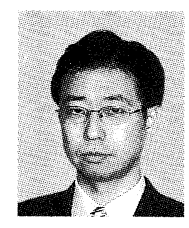

柴田哲男 名古屋工業大学大学院工学研究科 ながれ領域・助教授 薬学博士 〔経歴〕1993 年大阪大学大学院薬学研究科博 士課程修了, 同年大阪大学薬学部博士研究 員, オックスフォード大学博士研究員, 相模 中央化学研究所研究員, 富山医科薬科大学薬 学部講師を経て 2003 年より現職。2000 年度 有機合成化学協会武田薬品工業研究企画賞, 2003 年度有機合成化学協会富士写真フイル 厶研究企画賞受賞。[専門〕有機合成化学, 医薬品化学。〔連絡先〕e-mail: 